\title{
ALGUNAS CONSIDERACIONES ACERCA DE LOS BRONCES ECUESTRES ITALIANOS DE CARLOS II: VICISITUDES, RELACIONES, USOS Y FUNCIONES
}

\author{
Álvaro Pascual Chenel \\ Instituto de Historia, CCHS, CSIC
}

\begin{abstract}
Muy pocos son los retratos escultóricos conservados de Carlos II. Entre ellos especial relevancia ocupan los ecuestres, tanto desde el punto de vista artístico como histórico y significante. Se conocen tres ejemplares muy relacionados entre sí. El presente artículo estudia su conjunto en relación con las circunstancias históricas que rodearon su encargo, así como su uso y función en las relaciones diplomáticas.
\end{abstract}

Palabras clave: Retratos reales; Bernini; Diplomacia; Escultura; Foggini; Serpotta.

\section{SOME CONSIDERATIONS CONCERNING THE ITALIAN BRONZE EQUESTRIAN STATUES OF CHARLES II}

There are very few extant sculpted portraits of Charles II of Spain. Among those preserved, the equestrian portraits are especially relevant from both the artistic and historical points of view. Only three of these works -closely related to each other-are known. This article studies them in relation to the historical circumstances surrounding their commission, and their function in diplomatic relations.

Key words: Royal portraits; Bernini; Diplomacy; Sculpture; Foggini; Serpotta.

Sabido es que el arte, más allá de su valor estético y plástico, jugó un importantísimo papel como eficaz instrumento al servicio del poder y la diplomacia, y a nadie le escapa ya el hecho de que la obra artística, fuese cual fuese su naturaleza, fue un objeto de vital trascendencia en las relaciones internacionales ${ }^{1}$ convirtiéndose así en verdaderos documentos histórico-visuales. Ciertamente, especial significación tiene en este ámbito el retrato, pues fue uno de los objetos preferidos como regalo de agasajo diplomático, lo cual, de paso, nos está hablando de uno de los variados usos y funciones que se le otorgaron ${ }^{2}$.

\footnotetext{
1 Véase al respecto Cropper (ed.), 2000. Martín García, 2002. Colomer, 2003. Dandelet y Marino (ed.), 2007. Hernando SÁnchez (coord.), 2007. Aguiló Alonso, 2008: 49-62. García Cueto, 2009: 293-322. Martínez Millán y RIVERO RODRÍGUEZ (coords.), 2010.

2 Pascual Chenel, 2009a: 183-223.
} 

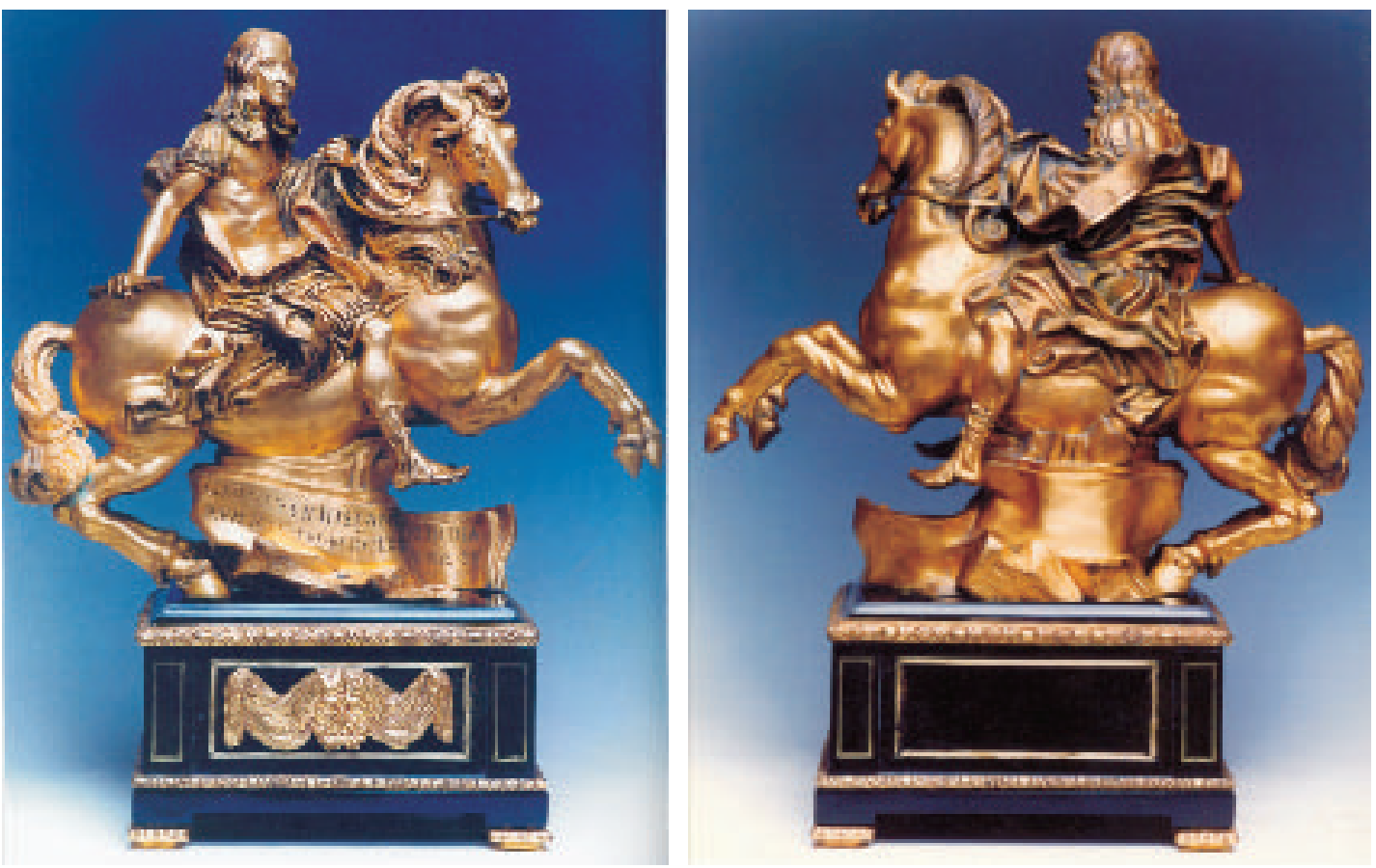

Fig. 1. Bernini (atrib.) y anónimo fundidor, Carlos II a caballo, París, Colección particular, 1680.

Un ejemplo evidente de todo ello lo encontramos en una interesante operación artística llevada a cabo por el célebre Marqués del Carpio cuando era embajador en Roma. Se concreta ésta en el supuesto encargo a Bernini de una pequeña estatua en bronce con la imagen ecuestre del rey Carlos II que, al parecer, hoy podría conservarse en Estados Unidos (fig. 1) y tras la que se esconden sugestivas cuestiones en relación con las circunstancias que rodearon su gestación. Son precisamente esos otros asuntos "no estrictamente artísticos" los que conectan también dicha escultura con las otras dos únicas ecuestres conservadas (al menos conocidas) del rey: la de Foggini del Museo del Prado ${ }^{3}$ y la de Serpotta conservada en el Museo Pepoli de Trapani ${ }^{4}$. Por eso, los bronces que nos ocupan cobran una especial relevancia tanto desde el punto de vista artístico e iconográfico como histórico ${ }^{5}$.

La escultura, propiedad de una galería anticuaria de París, había permanecido inédita y desconocida hasta no hace muchos años ${ }^{6}$. A primera vista resulta evidente la estrecha relación de

${ }^{3}$ Pascual Chenel, 2009b: 72-84.

${ }^{4}$ Pascual Chenel, 2012 (en prensa).

5 Recientemente se ha celebrado en el Palacio Real de Madrid una exposición sobre los bronces de la Colección Real española, en la que se analizan también las colecciones francesa e inglesa. Sólo el bronce de Foggini perteneció a la colección real y aunque ninguna de las obras aquí mencionadas han sido expuestas, sí aparecen citados los bronces del Museo del Prado y el de París. Véase Coppel y Herrero Sanz (Comisarias), 2009: 33-34.

${ }^{6}$ Fagiolo dell'ArCo, 2002: 120-123. Montanari, 2003: 403-413. Ambos autores dieron a conocer, por separado, la escultura que permanecía inédita y desconocida hasta ese momento. Las medidas que ofrece cada uno difieren notablemente. Así, 41 (alto) $\times 48$ (ancho) $\times 17$ (largo) cm., en Fagiolo dell'Arco, mientras, Montanari nos da $54 \times 48 \times 25$. Hasta donde tengo noticia, la obra se encontraba en la Galería anticuaria Charles Ratton \& Guy Ladrière de París al menos desde 1999. Sin embargo, años después, en Ribot, 2009, p. 355, se cita como en colección particular estadounidense. 
este pequeño bronce con los grandes monumentos ecuestres realizados por Bernini en Roma, el del emperador Constantino de la Scala Regia del Vaticano y, sobre todo, el del rey Luis $\mathrm{XIV}^{7}$ (fig. 2), transformado poco después en un Marco Curcio entre las llamas, y condenado al ostracismo en los jardines de Versalles ${ }^{8}$.

Parece claro que este magnífico bronce representando a Carlos II es una adaptación en pequeño formato del monumental retrato ecuestre del Rey Sol esculpido por Bernini entre 1669, en que realiza el conocido modelo en terracota que hoy se conserva en la Galería Borghese, y 1677, fecha de conclusión de la estatua ${ }^{9}$.

La estatua "parisina" está realizada en bronce dorado, representa a Carlos II a la heroica, vestido all'antica, de modo muy similar a como le vemos en la pieza del

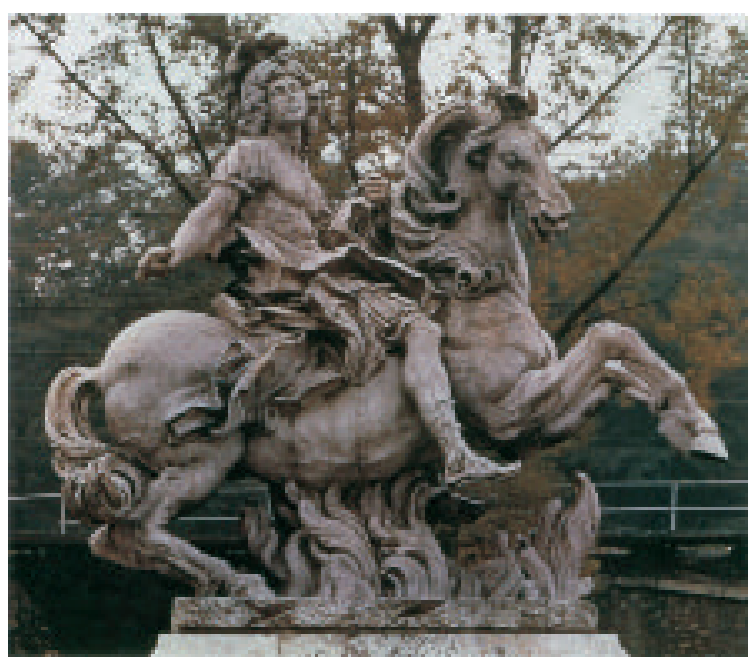

Fig. 2. Bernini y François Girardon, Monumento ecuestre de Luis XIV transformado en Marco Crucio entre las llamas, Versalles, 1677-1688. Prado, aunque en este caso la loriga presenta menos detalle que en la obra de Foggini y se incluyen las riendas, motivo que Bernini elimina en sus otros monumentos ecuestres. En la parte inferior, uniendo el vientre del caballo con el pedestal, se coloca una roca, tal y como debió haber en origen en la estatua de Luis XIV (sustituida después por Girardon por las llamas a las que se arroja Marco Curcio), a la que se añade una cartela que data la obra en 1680, cuando Carlos II tenía 19 años.

Es tal vez en el comitente de la obra donde podamos ver otro nexo de unión indirecto entre las tres esculturas. Nos encontramos que, por esas mismas fechas, el embajador español en Roma era don Gaspar de Haro y Guzmán (1629-1687), VII marqués del Carpio, uno de los mayores expertos y coleccionistas de arte de la época, hijo del valido de Felipe IV, don Luis, y sobrinonieto del todopoderoso Gaspar de Guzmán, conde-duque de Olivares.

Don Gaspar de Haro había iniciado su carrera diplomático-administrativa muy joven, durante el reinado de Felipe IV, bajo la protección de su poderoso padre. Tras una turbulenta vida y cursus honorum, fue nombrado embajador en Roma con la intención de alejarle definitivamente de la corte y el favor regio. Ocupó el puesto desde 1676 hasta 1682 en que se le nombró virrey de Nápoles, donde residió hasta su muerte en $1687^{10}$.

Consultadas las bases de datos sobre subastas, no consta que la escultura haya salido a pública subasta, por lo que no he podido localizar su venta, quedando su ubicación actual un tanto incierta. Véase también DeL PESCO, 2004: 313-324.

7 Del Pesco, 2004: 313-324.

${ }^{8}$ La desgraciada historia de la estatua es bien conocida y resulta trágicamente irónico que acabara transformada en un Marco Curcio por Girardon, cuando el propio padre de Bernini había transformado un caballo helenístico que se conservaba en villa Borghese, añadiéndole precisamente la figura de Marco Curcio. La larga y tormentosa historia del monumento ecuestre de Luis XIV desde su inicial gestación hasta su damnatio memoriae a manos de uno de los discípulos de Bernini (François Girardon), quedó plasmada en WitTKOWER, 1961: 497-531. Sobre el devenir posterior de la estatua, ya en Francia y en Versalles, véase BERGER, 1981: 232-248.

9 WiTTKOWER, 1990: n. ${ }^{\circ}$ 73, 291-294.

${ }^{10}$ La bibliografía sobre el personaje y sus impresionantes colecciones es abundante y variada por lo que tan sólo 
Si conocida es su carrera política desde joven, incluyendo algunos oscuros episodios, no lo es menos su paralela faceta de experto conocedor, protector y coleccionista de arte, iniciada en Madrid en sus años mozos pero que alcanzaría su culminación durante su estancia italiana, llegando a reunir una de las más espectaculares colecciones artísticas de la época que acabaría dispersándose en sucesivas ventas tras su fallecimiento.

En Roma llevó a cabo una importante labor como mecenas de las artes y de la cultura, participando activamente en la vida social y cultural de la Urbe y relacionándose con los intelectuales y artistas más relevantes del momento. Bien conocida es su admiración por Gian Lorenzo Bernini y su inclinación por hacerse con reducciones de grandes obras del escultor napolitano, entre las que destaca una copia de la Fontana dei Fiumi de la Plaza Navona ${ }^{11}$, encargada al propio Bernini al final de su vida y en la que incluso parece que se incluyó un retrato del escultor, junto a las armas del Marqués y una inscripción laudatoria de ambos, dejando bien claro de este modo quién había sido el comitente y quién el autor ${ }^{12}$. A ésta se unía una reducción del David ${ }^{13}$, adquirida posteriormente por el propio Carlos $\mathrm{II}^{14}$, y Due mascaroni di Creta cotta fatti dal Cavalier Bernino con loro Cornicie tonde indorate di legno ${ }^{15}$.

No sería por tanto descabellado pensar que pudiese haber sido el propio Don Gaspar quien encargase y obtuviese del mismo Bernini, en la época en que supervisaba la pequeña copia de la Fontana, la reducción de su estatua ecuestre de Luis XIV, transformándolo en Carlos $\mathrm{II}^{16}$. Tal vez en este encargo del Marqués operasen varias consideraciones e intenciones que trascienden el ámbito puramente artístico. En primer lugar, recordemos la pintoresca historia, acontecida cuatro años antes, del encargo de la estatua ecuestre de Carlos II realizado por Valenzuela y Mariana de Austria a Florencia, para acompañar en la fachada del Alcázar a la de Felipe IV realizada por Pietro Tacca 35 años antes ${ }^{17}$.

Efectivamente, a partir de 1674, el nuevo valido Fernando de Valenzuela inició una serie de obras arquitectónicas en el Alcázar madrileño, con todo un programa decorativo de la plaza y la fachada. La culminación del mismo consistía en un ambicioso proyecto escultórico con fines propagandísticos y de glorificación de la monarquía hispánica, con la inclusión de diferentes estatuas de los antepasados de Carlos II y, sobre todo, lo que resulta más interesante, la colocación en la fachada del Alcázar, en 1675, de la estatua ecuestre de Felipe IV ${ }^{18}$. Tras los sucesos ocurridos con la proclamación de la mayoría de edad del rey, Valenzuela fue alejado temporalmente de la corte, volviendo sin embargo en 1676 bajo la protección de doña Mariana que le encumbró definitivamente al nombrarle primer ministro de la Monarquía ${ }^{19}$.

referiremos aquí algunos de los estudios más generales, significativos o recientes que incluyen ya los anteriores. CACCiOTi, 1994: 133-196. Burke y Cherry, 1997. De Frutos SAstre, 2006; 2009a.

11 Avery, 2003: 427-464. Estella, 2008: 24-27. Véase también, RodríGuez RuIz, 2003: 26-41.

12 CAcсіоті, 1994: 138, 177, 184 y 191.

13 Tasación de los bienes del Marqués realizada en Madrid en 1689: "Mas ottra estatua de bronce de una bara de alto de David sacada por el original del Cavallero Bernini vale ocho mill reales"; Archivo Histórico de Protocolos de Madrid (AHPM), protocolo 9819, f. 979r. Fernández Talaya, 1999: 141. De Frutos Sastre, 2009a, apéndice documental: 622 .

14 AHPM, 9819, f. 1182r. Fernández Talaya, 1999: 141. De Frutos Sastre, 2009a, apéndice documental: 625.

15 Inventario de la colección del Marqués, realizado en 1682 en Roma, con ocasión de su partida hacia Nápoles como virrey, Archivo de la Fundación Casa de Alba (AFCA), caja 302, n. ${ }^{\circ}$ 4, f. 166v. La parte referente a la escultura fue transcrita por CACCIOTI, 1994: 189-193; la cita relativa a esta obra de Bernini en posesión del Marqués del Carpio en p. 190.

16 Montanari, 2003: 411-412.

17 Sobre la estatua véase MATILla RodRíGUEZ, 1999: 50-59; 1997.

18 Hellwig Konnerth, 1990: 233-241.

${ }^{19}$ Las obras principales e indispensables sobre el reinado de Carlos II continúan siendo la del DuQUE DE MAURA, 1911-1915; 1990. Otras obras clásicas son las de Juderías, 1912. PfandL, 1947. KamEN, 1981. Más Recientemente el 
Es en este convulso contexto histórico-político donde tiene lugar toda la peripecia de la "subida" de la estatua de Felipe IV a la fachada del Alcázar, cargada de profunda significación política. Sin embargo, el proyecto de ensalzamiento dinástico ideado por Valenzuela y la regente, no adquiriría pleno sentido hasta que una estatua de Carlos II, ya mayor de edad, no flanquease a la de su padre. Así, una vez regresado Valenzuela a la corte investido de los máximos poderes, se acudió al Gran Duque de Toscana, Cosimo III, para solicitarle la realización de una monumental estatua ecuestre en bronce de Carlos II a semejanza de la de su padre, con objeto de completar el programa decorativo y propagandístico iniciado un par de años antes ${ }^{20}$. De la documentación se desprende que, para llevar a término el encargo, se consideró como el mejor artífice al hijo mayor del propio Tacca, Ferdinando ${ }^{21}$, que, debido a la carga de trabajo que suponía, estaría ayudado por otros dos jóvenes escultores florentinos que se encontraban en aquellos momentos estudiando en Roma ${ }^{22}$. Uno de ellos era precisamente Giovanni Battista Foggini, enviado a la Urbe por el mismo Gran Duque con fines de estudio y aprendizaje ${ }^{23}$ y llamado ahora de vuelta a Florencia para ayudar en la realización de la escultura ${ }^{24}$.

Sabemos, sin embargo, que la culminación

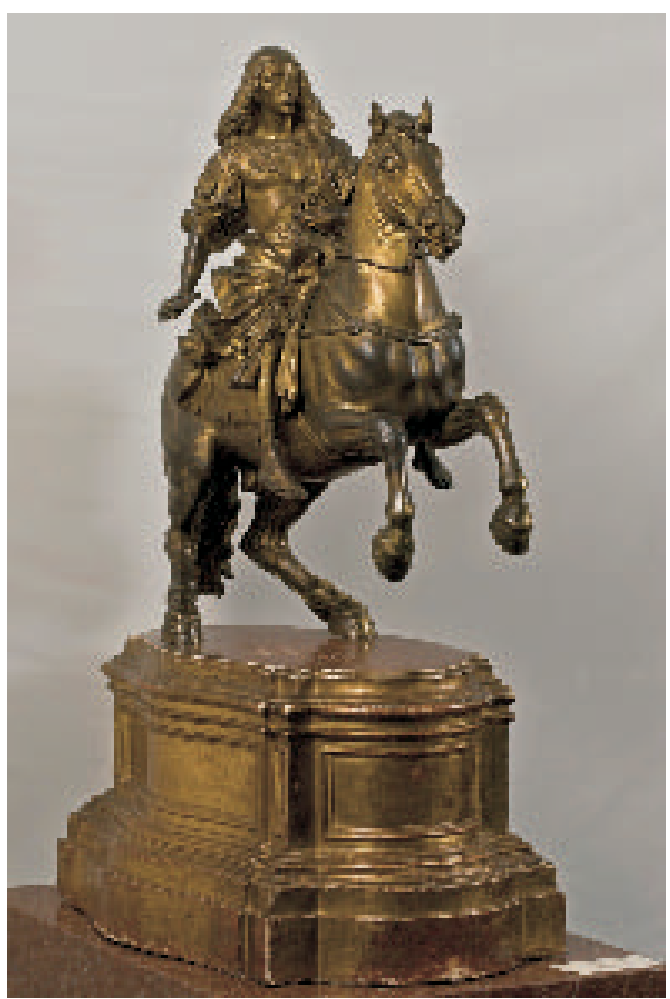

Fig. 3. Giovanni Battista Foggini, Carlos II a caballo, Madrid, Museo Nacional del Prado, 1698. del ambicioso proyecto ideado por el valido en connivencia con su protectora doña Mariana, nunca fue llevado a cabo y que, consecuentemente, la escultura monumental de Carlos II jamás llegó a ser fundida. Ello se debió a la caída de su principal inspirador, forzada por la nobleza y rematada militarmente por Juan José de Austria que se convertía, por la fuerza, en el nuevo primer ministro de la Monarquía. Inmediatamente después

estudio de CONTRERAS, 2003. Existen también valiosas síntesis del reinado entre las que cabe destacar la realizada por Riвот, 1993: 63-203. A estas referencias habría que añadir otra obra de reciente aparición sobre diversas cuestiones del reinado, dirigida por Riвот, 2009. En ella se incluye un capítulo de José Luis Sancho y José Luis Souto, dedicado a la representación del rey, en el que, a modo de valiosa síntesis, se hace un recorrido iconográfíco por todo el reinado.

20 BROOK, 1996: 112-125.

21 BROOK, 1996: apéndice doc. 2.

22 BROOK, 1996: apéndice doc. 5.

23 Así lo indicaba Baldinucci en la vida de Foggini: Cosimo 3. ${ }^{\circ}$, il quale considerando che a poco a poco mancava in Firenze la bell'Arte della Scultura e della statuaria pensò providamente di ristabilirla con tirare avanti più Giovani di buona espettazione che con lo studio e applicazione loro all'antico ottimo stato le restituissero. Per uno di questi fra gl'altri prescelse il nostro Gio. Batista Foggini, il quale fu mandato e mantenuto generosamente a Roma [...] In questa forma stiede Gio. Batista in Roma usando ogni assiduità e fatica nella arte sua per lo spazio d'anni tre e mezzo in circa, e di poi richiamato da S.A.R. carico di disegni e modelli d'ogni sorta fatti dalla mano sua, tornossene alla patria [...]; LANKHEIT, 1962, doc. 48: 233.

${ }^{24}$ LANKHEIT, 1962, doc. 105: 253; doc. 108: 254. 
de su ascenso al poder, Don Juan José comenzó su gobierno con el lógico alejamiento de sus enemigos. La reina madre fue confinada en el Alcázar de Toledo y Valenzuela, desposeído de todos sus honores y títulos, confiscados sus bienes y propiedades, fue encarcelado y más tarde exiliado. Recuerdo de lo que debió ser aquel encargo podría ser la pequeña estatua ecuestre de Carlos II (fig. 3), que Foggini realizara muchos años después a petición del nuevo nuncio de Su Santidad, monseñor Archinto, para regalársela al monarca a su llegada a Madrid, pues se había convertido en costumbre frecuente entre cargos diplomáticos, cuando ocupaban la plaza, obsequiar al soberano con una estatua suya a pequeña escala ${ }^{25}$.

Es muy improbable que el Marqués, que era ya embajador en Roma cuando Foggini recibía el encargo de la estatua de Carlos II, no estuviese al corriente de todos los acontecimientos y de la marcha de los trabajos. Podría ser que, una vez abandonado el ambicioso proyecto referido, tras la caída de su principal valedor, el Marqués mantuviese viva la idea con el propósito de resucitarla algún día, en un intento de recuperar el perdido favor regio ${ }^{26}$. La ocasión idónea se le ofreció precisamente en Roma, donde ese contacto directo con Bernini podía proporcionarle una obra sin parangón en su clase. Como ya se ha apuntado, tal vez no sólo existiesen razones meramente artísticas de querer contar con una obra realizada por el escultor más famoso e importante de la época. Quizá tras esta operación de reducción de la estatua de Luis XIV y su conversión en Carlos II, se ocultase una estrategia diplomática del Marqués por intentar acercar de nuevo a Bernini al servicio del Rey de España, lanzando, de paso, un dardo envenenado a la Francia de Luis XIV, que había desairado al gran escultor al desestimar la estatua ecuestre del monarca galo, cuya desgraciada historia es perfectamente conocida ${ }^{27}$.

En este punto merece la pena también evocar los avatares artístico-diplomáticos que tuvieron lugar en Roma hacia 1660-1666, en torno a varios tormentosos proyectos escultóricos estrechamente relacionados entre sí en los que, de una u otra forma, participó el propio Bernini. Son éstos la Scala Regia del Vaticano con su culminación en el Constantino, la escalinata de Trinità dei Monti que preveía la inclusión de una estatua en bronce de Luis XIV (finalmente llevada a cabo en mármol aunque ya no vinculada a la escalinata) y la monumental efigie de Felipe IV para la Basílica de Santa María Maggiore, impulsada por el embajador Pedro Antonio de Aragón, que, aunque terminada hacía tiempo, permanecía todavía sin exhibir durante la embajada del Marqués del Carpio. En realidad, disimulada tras estas magnas intervenciones y encargos artísticos, lo que se dirimía era la lucha por la preponderancia política entre la Monarquía Católica, Francia y el Papado ${ }^{28}$.

En los inventarios de la colección del Marqués se menciona en varias ocasiones una estatua ecuestre de Carlos II que ha sido identificada con la de la galería parisina. Así, en el inventario redactado en Roma en 1682, cuando don Gaspar partía para Nápoles como Virrey, se describe Un Ritratto di bronzo che rappresenta il Re Carlo secondo delle Spagne Nostro Sig.re che Dio guardi à Cavallo, con sotto nobile Piedestallo ${ }^{29}$. Años después la misma obra debe ser la que aparece relacionada entre los bienes que fueron enviados desde Nápoles a Madrid, en enero de 1687, poco antes de la muerte del virrey, embarcada en la caja n. ${ }^{\circ} 20$ y referida como "La estatua de bronce sobredorado del Rey Carlos $2 .^{\circ}$ á cavallo con su Piedestal" 30 . El interés por el envío de su colección desde Nápoles a Madrid, entre los años 1683-1687, demuestra cómo el Marqués no había perdido la esperanza de regresar a España, cosa que no pudo ver finalmente cumplida.

25 Pascual Chenel, 2009b: 72-84.

26 MONTANARI, 2003: 410.

27 Montanari, 2003: 412. Del Pesco, 2004: 313-324.

28 CARrió-INVERNIZZI, 2007: 255-270. VisCEGLIA, 2010.

29 AFCA, caja 302, n. ${ }^{\circ}$ 4, f. 163r; en CACCIOTI, 1994: 189.

${ }^{30}$ Real Biblioteca del Monasterio de El Escorial, manuscrito \&-IV-25, f. 29v. Citado por Fagiolo dell'Arco, 2002: 122, sin indicar folio. 
Tras la muerte del virrey y ante las acuciantes deudas, se hacía necesaria la venta de sus fabulosas colecciones. Con este propósito, en 1688 se elaboró otro inventario de los bienes presentes en las varias propiedades de Madrid que habían llegado ya de Nápoles, en previsión de la almoneda de los mismos. Allí de nuevo aparece descrita la estatua: "Mas Una efigie del Rey nro $\mathrm{S}^{\mathrm{r}}$ Carlos Segundo â cavallo de bronze dorada con peana de diferentes piedras embutida de porfido con las armas reales y la peana con sus molduras de bronce dorado" ${ }^{31}$. Posteriormente, en 1689 , se hace una tasación de todos los bienes donde ya figuran los precios estimados de salida en la inminente subasta. Dicha tasación se realiza en varias tandas, ocupándose en primer lugar de todo lo que se refería a bienes inmuebles (casas, jardines, huertas, prados, bosques, etc.), así como la impresionante biblioteca y las estatuas de yeso ${ }^{32}$. En una segunda tanda, se escogen peritos para tasar los variados y numerosísimos bienes, entre los que se incluían no sólo las pinturas $^{33}$ y esculturas, sino también tapicerías, bordados, alfombras, colgaduras de cama, instrumentos de música, sillas de mano, enseres de cocina, vidrios, espejos, mulas, caballos, objetos de plata, coches, instrumentos de matemática, joyas, armas, etc. ${ }^{34}$.

Encontramos tasado el retrato ecuestre de Carlos II en bronce, curiosamente no en el apartado de esculturas ni en el de "estatuas y cosas de piedra", encargado este último a unos marmo$\operatorname{listas}^{35}$, sino en la tasación hecha por Francisco Filippini ${ }^{36}$, maestro relojero, que debió considerarse más apto para objetos de bronce. Así pues, se tasan primero los relojes y después las esculturas de bronce en posesión del Marqués: "Mas una efigie del Rey nro señor Carlos Segundo a cavallo de bronce dorado con peana de diferentes piedras embutida de porfido con las armas reales y la peana con sus molduras de bronce dorado en once mill reales" ${ }^{\prime 37}$.

De la documentación conservada de la almoneda subsiguiente (a partir de 1689) parecería desprenderse que dicha escultura no encontró comprador, ya que no figura en los papeles referidos a las transacciones. Tampoco aparece entre los objetos adquiridos por el propio Carlos $\mathrm{II}^{38}$. En realidad, la venta de los bienes del Marqués se produjo en diferentes subastas y duró varios años, pagándose precios en ocasiones muy por debajo del valor tasado, e incluso utilizando los mismos cuadros como medio de pago a los diversos acreedores ${ }^{39}$, por lo que la colección sufrió una enorme dispersión y el destino de muchas de las obras de arte que la componían es a menudo difícilmente rastreable. Sin embargo, sí fue vendida. En los papeles de la venta se localiza una referencia inédita a la misma entre las obras de arte de que se hizo cargo Jerónimo Javierre, depositario de los bienes de la testamentaría del Marqués tras la almoneda: "Almoneda / idem efigie del Rey nro $\mathrm{S}^{\mathrm{r}}$ de bronce; vendida al ocho / Mas me hago cargo de cinco mill y quinientos $\mathrm{R}^{\mathrm{s}}$ de Vellon que valen 1870- mas en que se vendio al ocho Una efigie del Rey nro $\mathrm{S}^{\mathrm{r}}$ a cavallo de Bronce, sobre una peana de porfido y bronze tass ${ }^{\mathrm{da}}$ en $110-\mathrm{R}^{\mathrm{s}}$ $1870 " 40$.

31 AHPM, 9819, f. 825r. Citado incompleto en FAgIOLO DELL'ArCo, 2002: 122.

32 AHPM, 9819, ff. 834r-956r.

33 Para lo que fueron elegidos Claudio Coello, por aquel entonces pintor de cámara y José Donoso; AHPM, 9819, f. 958r. La tasación de la impresionante colección de pintura, en ff. 1006-1067.

${ }^{34}$ AHPM, 9819, ff. 960r-1005r.

35 El maestro Henriquez y Alonso de los Ríos. AHPM, 9819, ff. 958r-959r.

${ }^{36}$ Italiano, natural de Urbino, Francesco fue conocido relojero de cámara de su Majestad desde 1678. Trabajó también para el Ayuntamiento de Madrid e incluso para Don Juan José de Austria, gran aficionado y coleccionista de relojes. Véase Benito RuAno, 1969: 22-23. GonZÁLez Asenjo, 2005: 618-620.

37 AHPM, 9819, f. 978v. De Frutos SAStre, 2009a: 405, apéndice documental: 622.

38 AHPM, 9819, ff. 1175v-1184v.

39 Pita AndRade, 1952: 234.

40 AFCA, caja 221-2, " $D^{n}$ Germo Javierre depositario de los vienes de la testamentaria del Ex ${ }^{m o} S^{r}$ Marques del Carpio $D^{n}$ Gaspar de Haro y Guzman. Su cargo y de los mas que entran en su poder...”, f. 22r (sin numerar, la numeración es mía). 
Tras diversos y complejos avatares derivados de las deudas de Carpio con la Corona, la estatuilla, entre otras obras, fue comprada a finales de 1699 por el III Duque de Tursi, pasando así a engrosar sus colecciones genovesas ${ }^{41}$. Después le perdemos la pista. Es evidente que en algún momento y bajo unas circunstancias que todavía no se han podido determinar, el pequeño retrato ecuestre debió salir de entre los despojos de la antigua colección Carpio para ir a parar finalmente a París ${ }^{42}$ y, supuestamente, después a Estados Unidos, si es que se trata realmente de la misma escultura.

En realidad, a pesar de la evidencia documental, ésta no hace otra cosa sino probar que, entre las numerosísimas obras de arte que poseyó del Marqués, existió un retrato ecuestre en bronce de Carlos II, sin que nada nos permita afirmar con total seguridad que la escultura que se menciona en la documentación se corresponda con la de la galería parisina. En ningún momento se alude a Bernini como su autor, como sí se hace con otras obras que también pertenecieron a don Gaspar, como la famosa reducción de la Fontana dei Fiumi. Tal vez ello se deba a que Bernini, ya anciano (morirá en 1680), se limitase tan sólo a dirigir la labor de algún colaborador que sería realmente quien realizase materialmente la reducción y fusión de la estatua cambiando el rostro de Luis XIV por el de Carlos II $^{43}$, cosa que parece confirmar la presencia de las riendas, detalle que, como hemos visto, Bernini siempre prefirió obviar en sus otros retratos ecuestres ${ }^{44}$. A este respecto, resulta ciertamente llamativo el nulo "éxito" que la escultura tuvo después de todo, pasando sin pena ni gloria por los complejos avatares de las ventas. A pesar de ser ofrecida al Monarca, éste no sólo no la adquirió sino que, como hemos visto, incluso fue vendida "al ocho", y posteriormente nadie quiso comprarla por estar "maltratada", hecho que, además, motivó la devaluación de su precio ${ }^{45}$. Esto, desde luego, no parece apoyar la teoría de que efectivamente aquella escultura fuese obra de Bernini, tan deseosa como al parecer había estado la Monarquía por hacerse con los servicios del artista.

El hecho de que no se conozcan más estatuas en bronce del rey a caballo, y de tono tan berninesco de las que aquí mencionamos, ha permitido mantener la hipótesis de la identificación del ejemplar de París con la que perteneció al Marqués del Carpio, salida al parecer del entorno de Bernini ${ }^{46}$.

Ahora bien, una cosa que no queda del todo clara es por qué don Gaspar encargó la reducción escultórica transformándola en Carlos II. Es decir, parece evidente que fue el mismo Marqués tanto el comitente como el propietario de la obra, que permaneció en su poder hasta su muerte como demuestra la documentación mencionada. No obstante, si encargó la escultura como un regalo para el rey, cosa que se había convertido en práctica habitual como vimos, con el objeto de recobrar su favor, ¿por qué no se la llegó a regalar? Quizá su intención fuese entregársela en persona a su vuelta a Madrid -pues parece ser, como dijimos, que siempre mantuvo vivo el anhelo de regresar- y demostrar así a Carlos II su buen hacer y sus capacidades diplomáticas.

Tal vez en todo ello haya que tener en cuenta cierta rivalidad entre los mismos virreyes y diplomáticos hispanos en tierras italianas ${ }^{47}$, lo que podría también poner en conexión esta estatua con la última ecuestre conocida de Carlos II: el boceto en bronce realizado por Serpotta para el

41 FERnÁNDEZ-SANTOS ORTIZ-IRIBAS, 2003: 42-57.

42 Tal vez tengan que ver, precisamente, con las buenas relaciones y la cercanía entre el Duque de Tursi y el nuevo monarca Borbón. Fernández-SAntos OrTIZ-IrIBAs, 2003: 48.

43 Quizá Girolamo Lucenti, uno de los más activos colaboradores de Bernini que además ya había participado en una importante obra en relación con la Monarquía Católica: precisamente la monumental escultura de Felipe IV, vestido a la heroica, y colocada en el atrio de la basílica de Santa María Maggiore; véase, al respecto, OsTROw, 1991: 89-118.

44 MONTANARI, 2003: 409, 412.

45 FernándeZ-SANTOS Ortiz-IriBas, 2003, documentos n. ${ }^{\circ}$ 1: 50, n. ${ }^{\circ}$ 6: 54 y nota 50.

46 Fagiolo dell'ArCo, 2002: 122-123; MontAnARI, 2003: 410-412.

47 Sobre la intensa actividad artística de los diferentes virreyes hispanos en Nápoles durante el siglo XVII, véanse los numerosos trabajos agrupados en Colomer, 2009. De CAVI, 2009. 
monumento del rey en Mesina (fig. 4), que, además, siempre se suele poner en relación con el bronce de Foggini.

Efectivamente, en la misma época en que Carpio ocupaba el puesto de embajador en Roma, el virrey de Sicilia era Francisco de Benavides, conde de Santisteban, que ocupó el cargo de 1678 hasta $1687^{48}$. Será precisamente en Italia y no en España donde al fin se materialice aquel proyecto de realizar un gran retrato ecuestre esculpido de Carlos II, comparable a los de su padre y abuelo. Se trata del monumento que estuvo colocado en la plaza del Duomo de la ciudad de Me$\operatorname{sina}^{49}$, en el espacio que antes de la revuelta antiespañola había ocupado el palacio del Senado, que fue derruido ${ }^{50}$.

Como hemos visto, Santisteban llegó como virrey a Sicilia a finales de 1678 donde inició una dura represión que culminaría con la construcción del monumento ecuestre a Carlos II. Del mismo modo que el embajador Carpio debió conocer el proyecto fallido de la fachada del Alcázar de Madrid, con más razón debía estar aún más fresco en la memoria de don Francisco de Benavi-

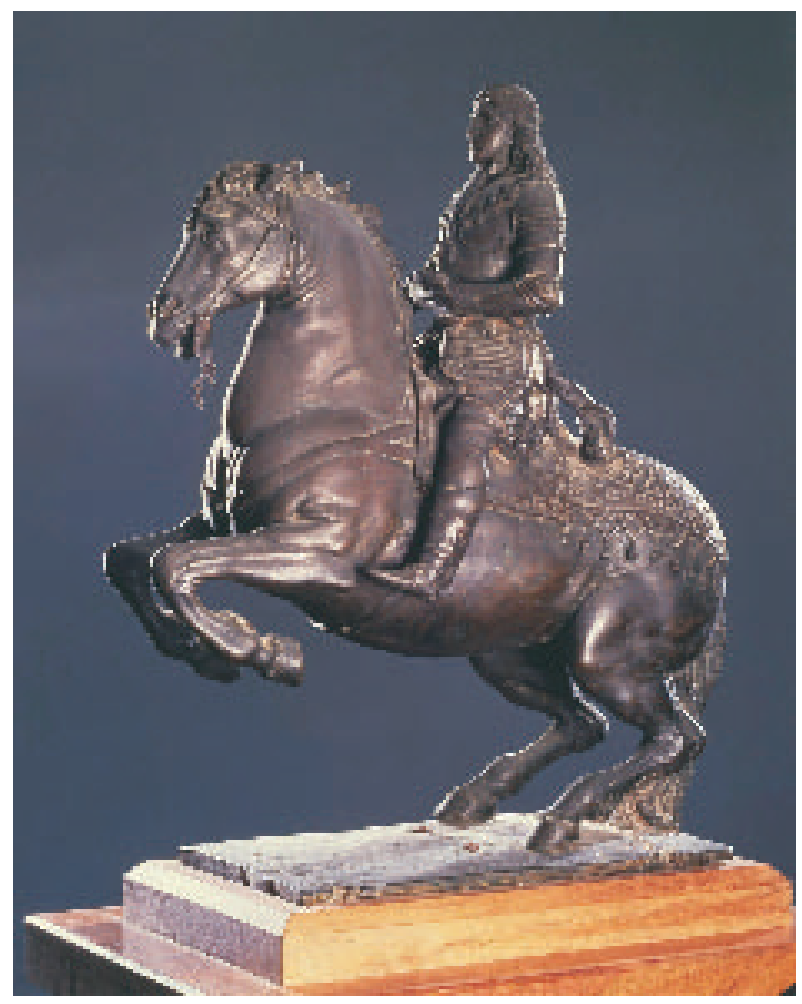

Fig. 4. Giacomo Serpotta, Carlos II a caballo, Trapani (Sicilia), Museo Pepoli, ca. 1680. des al que, una vez llegado a Mesina con el encargo de reprimir la rebelión, se le presentaba una inmejorable ocasión para agasajar al rey, materializando, ahora sí, lo que ni el todopoderoso Valenzuela había podido conseguir en la Corte. Evidentemente, si Carpio estaba enterado de los asuntos que ocurrían en Madrid, también estaría al tanto de los que acontecían en suelo italiano, por lo que debió ser conocedor de las intenciones y proyectos del virrey Santisteban.

En su memoria pudo estar también presente la vinculación iconográfica entre la imagen de su antecesor en ambos cargos, Pedro Antonio de Aragón, y la del rey niño llevada a cabo en 1667, ya como virrey de Nápoles (puesto que ocupó hasta 1672), en el hospital de San Genaro de aquella ciudad. Como decoración de la fachada, el nuevo virrey encargó un busto suyo y una escultura de cuerpo entero de Carlos II niño, realizadas por el marmolista Bartolomeo Mori ${ }^{51}$ (fig. 5). El mismo artista que participó en la ejecución de otra de las obras comisionadas por Pedro Antonio de Aragón al poco de ser nombrado virrey, con objeto de elogiar y ensalzar al

48 Curiosamente fue el designado para suceder precisamente a Carpio en el virreinato de Nápoles, ocupando el cargo hasta 1696. Sobre el personaje y sus actividades artísticas ya como Virrey de Nápoles véase CEREzo, 1986: 73-88. Lleó CAÑAL, 2009: 445-460. MuÑoz GonZÁLEZ, 2009: 461-480.

49 SALinas, 1884: 483-490. Sorrentino, 1913: 379-387.

50 RIBOT, 2002.

51 CARRIÓ-INVERNIZZI, 2008: 270-273. 

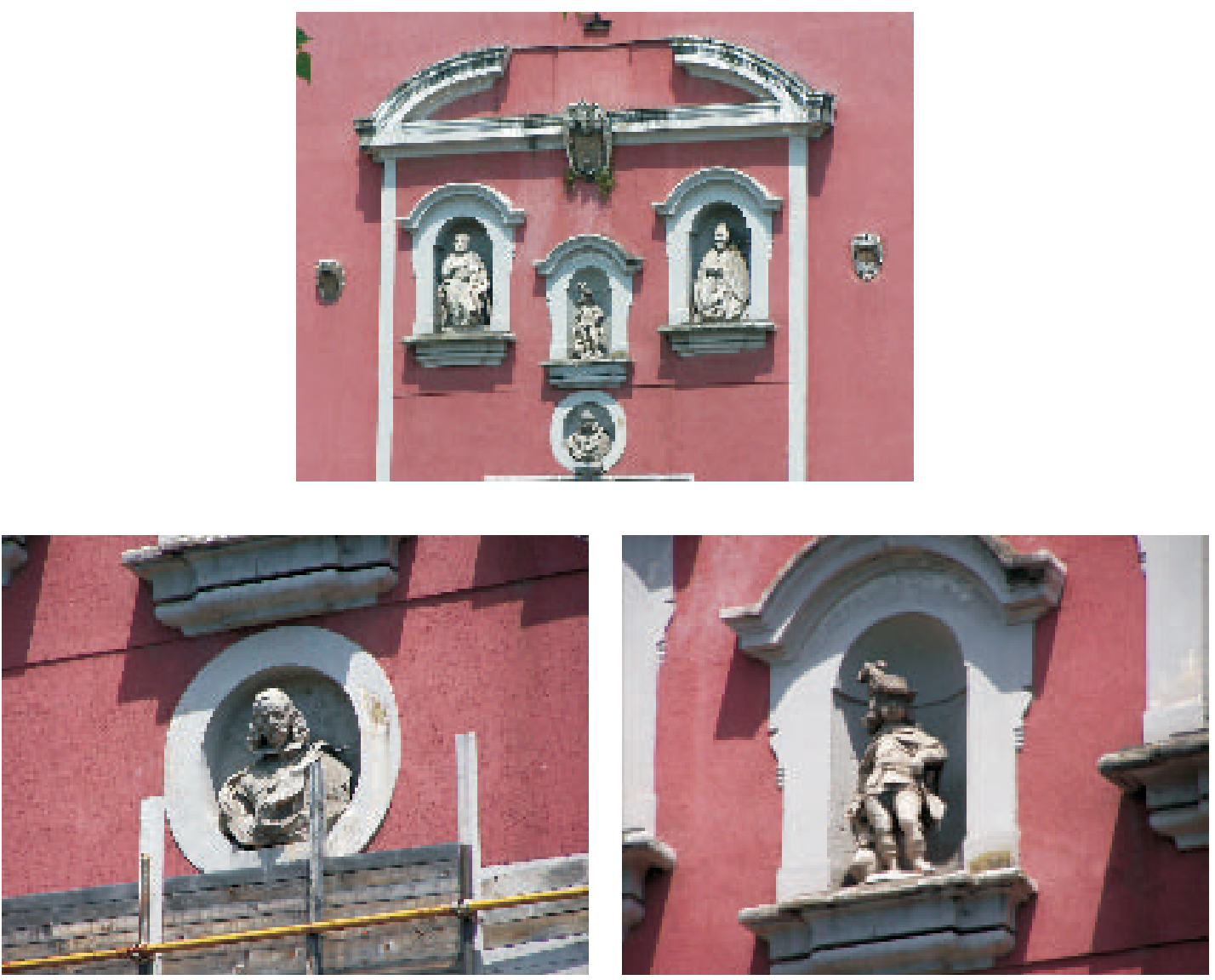

Fig. 5. Hospital de San Genaro, Nápoles. Fachada. Bartolomeo Mori, Esculturas de Pedro Antonio de Aragón y de Carlos II niño. 1667.

monarca y a sí mismo: la fontana de Monteoliveto, coronada por la estatua en bronce del rey ${ }^{52}$ (fig. 6). La plaza y la fuente con la escultura aparecen representadas en un interesante grabado de la obra de Domenico Antonio Parrino, Napoli citta' Nobilissima, Antica, e Fedelissima, publicada en Nápoles en $1700^{53}$ (fig. 7).

52 Strazzullo, 1969: 41-43, 53-55. NAPPI, 1980: 220-221, 229-231. CAntone, 1992: 237-239, 244; 2002: $342-$ 345, 348. Sobre otras esculturas de Carlos II en Avellino, Foggia, Capua, L'Aquila o la que estuvo en Lecce, véase BODART, 2009: 99-111.

53 Napoli città nobilissima, antica e fedelissima, esposta agli occhi et alla mente de' curiosi, divisa in due parti, contenendo in questa prima le sue più belle vedute intagliate in rame, chiese, castelli, fabbriche, magnificenze, notizie degli antichi dogi, regnanti, arcivescovi, vescovi, nobiltà, popolo, tribunali, quadri, statue, sepolchri, librarie e ciò che più di notabile, bello e buono in essa si contiene, epilogata da' suoi autori impressi e manoscritti, che ne hanno diffusamente trattato, col catalogo de' viceré, luogotenenti e capitani generali che han governato sino al presente, opera et industria di Domenico Antonio Parrino, natural cittadino napolitano. Volume primo. In Napoli, l'anno del Giubileo MDCC, nella nuova stampa del Parrino a Strada Toledo, all'insegna del Salvatore, con licenza de' superiori e privilegio, p. 101. 

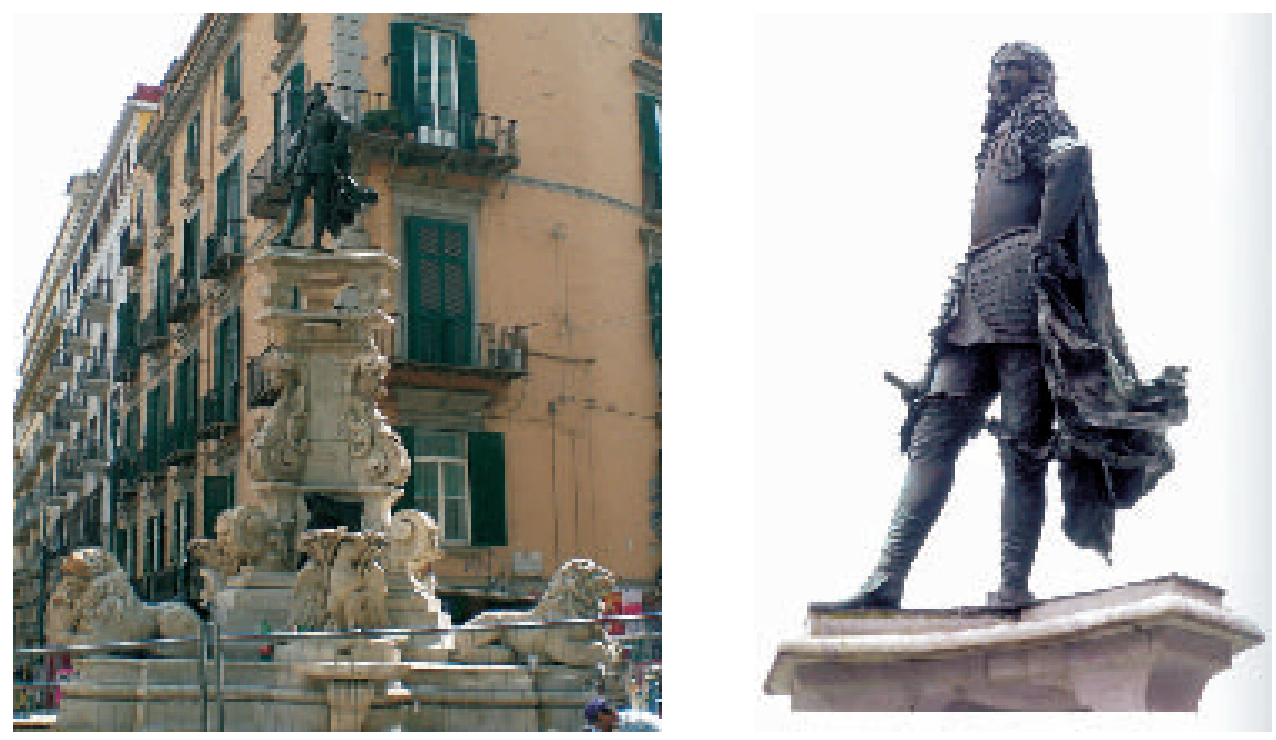

Fig. 6. Cosimo Fanzago y Francesco D’Angelo, Carlos II, Plaza de Monteoliveto, Nápoles, 1668-1676.

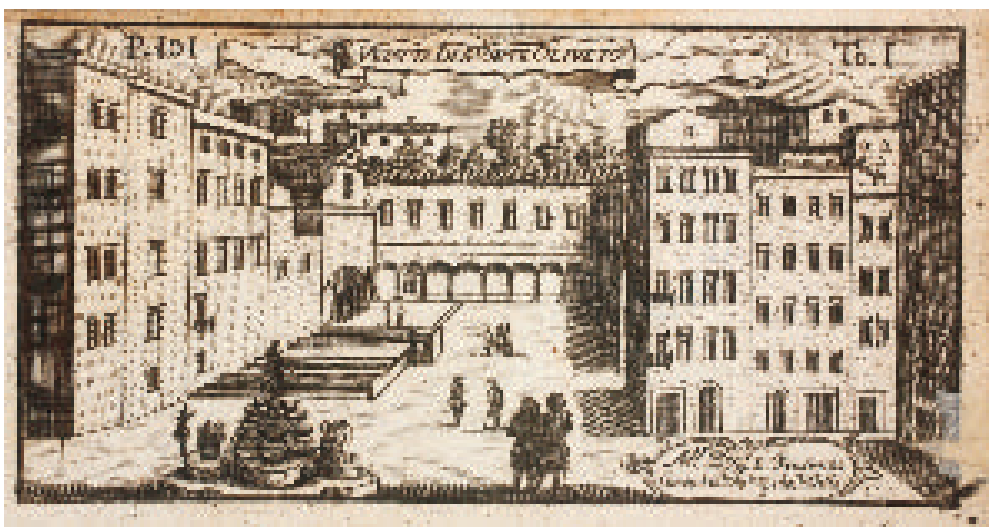

Fig. 7. Domenico Antonio Parrino, Vista de la plaza de Monteoliveto, grabado de Napoli citta' Nobilissima, Antica, e Fedelissima, Napoli, 1700, Nápoles, Biblioteca Nazionale.

Tal vez el encargo del embajador Carpio, casi contemporáneo al de Santisteban, pudiese enmarcarse dentro de una pugna diplomática y cortesana, disfrazada de "artística", por lisonjear a Carlos II. Si uno tenía la posibilidad de ejecutar finalmente un retrato ecuestre monumental para mayor gloria de Carlos II (y no poco propia ${ }^{54}$ ), el otro, sin embargo, podía conseguir que el escultor más célebre de la época realizase una reducción de una de sus obras más famosas, transformándola ahora en Carlos II, aumentando, de este modo, el esplendor de su soberano ${ }^{55}$.

${ }^{54}$ Allanaba el sendero que le conduciría a la ansiada grandeza de España; MuÑoz GonZÁlEz, 2009: 466.

55 Sus caminos de mecenazgo artístico se volverán a cruzar aún más estrechamente en Nápoles, al heredar Santisteban la labor de su antecesor Carpio como mediador del encargo de pinturas por parte de Carlos II a Luca Giordano. De Frutos Sastre, 2009b: 363-378. Lleó Cañal, 2009: 449-453. MuÑoz GonzÁlez, 2009: 466-480. 
En este sentido, resulta sumamente elocuente que en otra de las obras de Domenico Antonio Parrino, Teatro eroico, e politico de'governi de'vicere del regno di Napoli ${ }^{56}$, publicada en 1692 siendo virrey Santisteban, a quien está dedicada la obra y cuyo retrato aparece en la contraportada, se excluya de manera deliberada precisamente el virreinato de Carpio, del que, claro está, tampoco aparece su retrato grabado, como sí lo hace el del resto de los virreyes hispanos durante la Monarquía de los Austrias. La narración del texto acaba en 1683 con Fernando Joaquín Fajardo de Requesens y Toledo, VI marqués de los Vélez (1675-1683), antecesor real de Carpio y que, sin embargo, se presenta aquí como si lo fuera de Santisteban, alterando por tanto la lista en una suerte de damnatio memoriae.

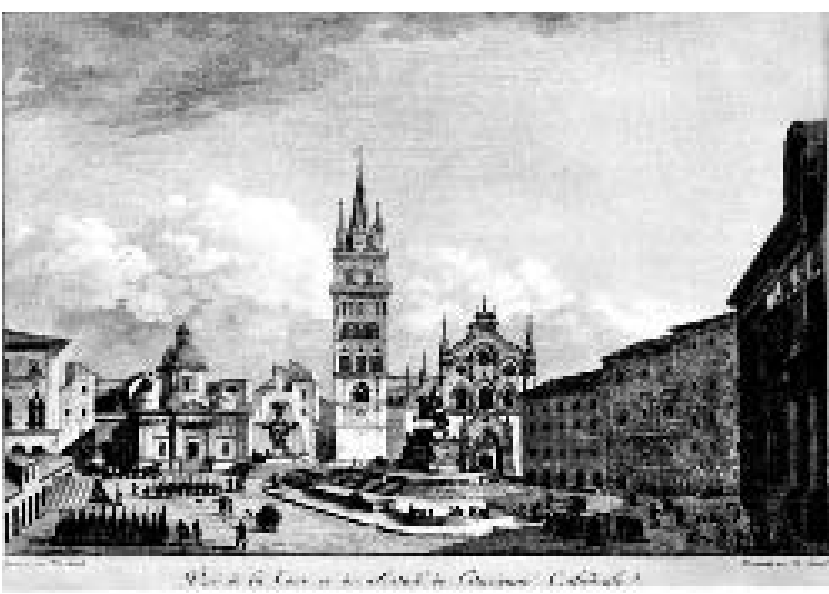

Fig. 8. Berthault e De Ghendt, Vista de la plaza del Duomo de Mesina con el monumento a Carlos II, Roma, Colección Basile Lemmerman.

El monumento ecuestre de Mesina se convertía así en un recordatorio permanente de la humillación y el castigo a la ciudad rebelde, así como del triunfo y poderío de la Monarquía y de Carlos II. Al mismo tiempo, servía de advertencia sobre las nefastas consecuencias que acarreaba a quien o quienes osasen atentar contra la autoridad real y la sumisión a la Monarquía, con el objetivo de disuadir posibles futuras revueltas.

Muy probablemente, el recuerdo trasmitido de generación en generación del sometimiento hacia la Monarquía Católica, la feroz represión y castigo infligido como consecuencia de la revuelta y el modo tremendamente ofensivo en que fue llevado a cabo, de todo lo cual era testimonio indeleble el grupo escultórico, debió crear un clima de odio antiespañol en la ciudad que determinó la destrucción del monumento ecuestre en el marco de exaltación revolucionaria de 1848. Así pues, menos de dos siglos más tarde, una venganza se pagaba con otra, siendo la "víctima", en este caso, una obra de arte como en tantas ocasiones ha ocurrido.

Del conjunto del perdido monumento ecuestre contamos con algunas imágenes que nos ofrecen diferentes versiones de una visión general de la plaza con el grupo escultórico colocado en el centro de la misma, encarado hacia el Duomo, lo que nos permite hacernos una idea de su aspecto e iconografía, pero sin que exista entre ellas una concordancia total al respecto ${ }^{57}$ (fig. 8). Además, se trata de generalizaciones iconográficas, pues no se observan muchos de los detalles que nos ofrecen las descripciones contemporáneas ${ }^{58}$. En cualquier caso, se trata de fuentes visuales de inestimable valor a falta del monumento real. Especial relevancia tienen aquellas que se

56 Teatro eroico, e politico de' governi de' vicere del regno di Napoli dal tempo del re Ferdinando il Cattolico fino al presente nel quale si narrano i fatti più illustri e singolari accaduti nella Città e Regno di Napoli nel corso di due Secoli, Come anche le fabbriche, iserizzioni, e leggi... Adornato... có Ritratti de'medesimi Vicere scolpiti in rame, presi da quelli, ch'adornano una delle Galerie del Palagio Reale / di Domenico Antonio Parrino, cittadino napolitano, 3 tomos, Napoli, 1692-1694. Se hizo una segunda impresión en 1730. Ejemplares de ambas se conservan, por ejemplo, en la Biblioteca Nacional de España, así como una copia de la edición original en el fondo Antiguo de la Biblioteca de la Universidad de Sevilla de la que hay reproducción digital.

57 CARANDENTE, 1967: 95, nota 44.

58 Pascual Chenel, 2012 (en prensa). 


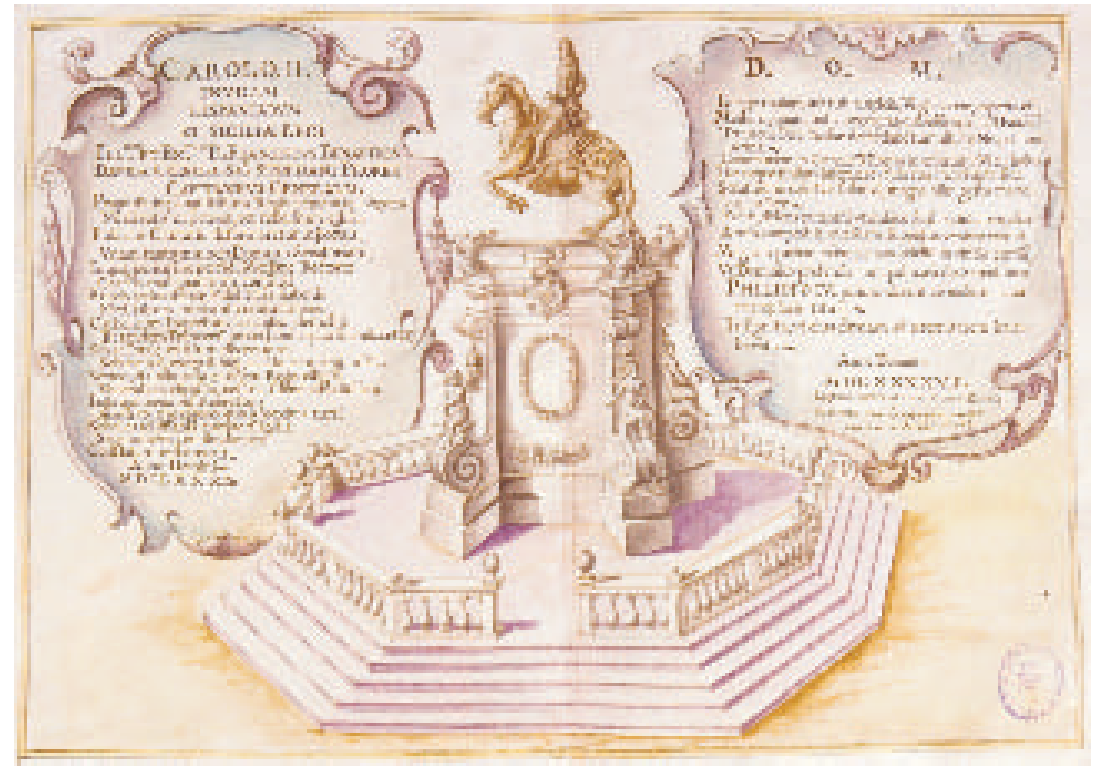

Fig. 9. Monumento ecuestre a Carlos II en Mesina, ilustración de Teatro geográfico antiguo y moderno del reyno de Sicilia, Madrid, 1686, Archivo general del Ministerio de Asuntos Exteriores.
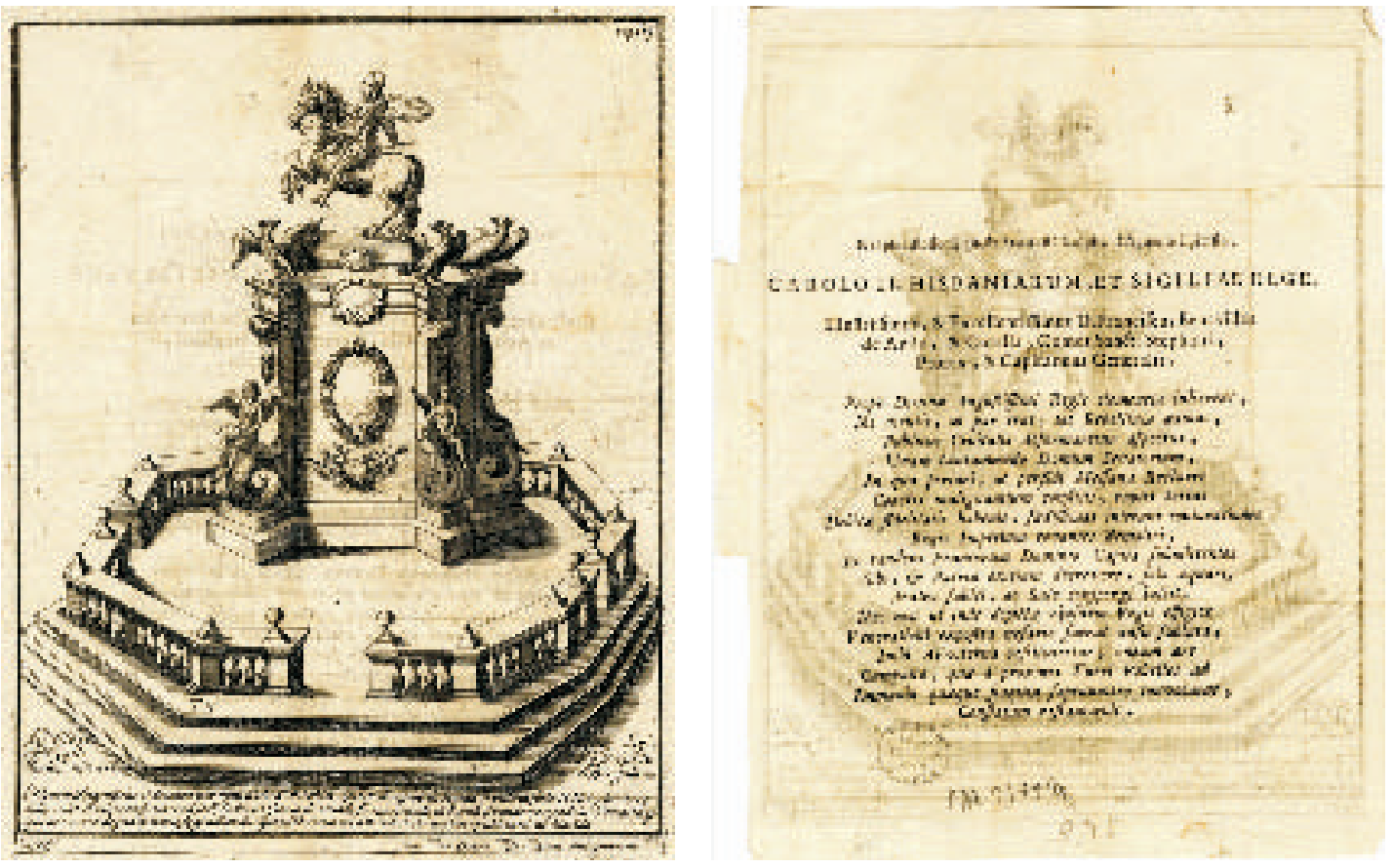

Fig. 10. Domenico Antonio Parrino, Monumento ecuestre a Carlos II en Mesina, grabado de Teatro eroico, e politico de' governi de' vicere del regno di Napoli..., 1694, Londres, British Museum.

Arch. esp. arte, LXXXv, 338, ABRIL-JUNIO 2012, 165-180, ISSN: 0004-0428 
centran en reproducir el grupo escultórico, como el conocido dibujo, ilustración del famoso Teatro geográfico antiguo y moderno del reyno de Sicilia, publicado en Madrid en 1686 y conservado en el Archivo General del Ministerio de Asuntos Exteriores ${ }^{59}$ que reproduce no sólo el monumento sino también la laudatoria inscripción que lo exornaba ${ }^{60}$ (fig. 9).

A este respecto es también muy interesante el grabado que Domenico Antonio Parrino incluye en la última obra citada ${ }^{61}$ reproduciendo el monumento ecuestre, así como la inscripción en el verso (fig. 10).

Pero sin duda, lo más importante y notable de todo es que, afortunadamente, conservamos el boceto original de la escultura ecuestre en bronce realizada por Serpotta, que se custodia en el Museo Pepoli de Trapani en Sicilia ${ }^{62}$.

\section{BIBLIOGRAFÍA}

Aguiló Alonso, María Paz, "Lujo y religiosidad: el regalo diplomático en el siglo XVII", en Cabañas Bravo, Miguel, López-Yarto Elizalde, Amelia y Rincón García, Wifredo (coords.), Arte, poder y sociedad en la España de los siglos XV a XX, Madrid, CSIC, 2008, pp. 49-62.

Avery, Charles, "The Duke of Marlborough as a Collector and Patron of Sculpture", The Evolution of English Collecting: Receptions of Italian Art in the Tudor and Stuart Periods, Edited by Edward Chaney, New Haven-London, Yale University Press, 2003, pp. 427-464 (Studies in British Art, 12).

Benito Ruano, Eloy, "Relojes y Relojeros del Ayuntamiento de Madrid en el siglo XVII", Anales del Instituto de Estudios Madrileños, tomo IV, 1969, pp. 22-23.

Berger, Robert W., "Bernini's Louis XIV Equestrian: A Closer Examination of Its Fortunes at Versailles", The Art Bulletin, vol. LXIII, 2, junio de 1981, pp. 232-248.

Bodart, Diane H., "Statues royales et géographie du pouvoir sous les régnes de Charles II et de Louis XIV", en Sabatier, Gérard y Torrione, Margarita (dir.), ¿Louis XIV espagnol? Madrid et Versailles, images et modèles, Centre de recherche du château de Versailles, Éditions de la Maison des sciences de l'homme, Colecction Aulica, Versailles-Paris, 2009, pp. 95-118.

Burke, Marcus B. y Cherry, Peter, Collections of paintings in Madrid, 1601-1775, 2 vols., Los Angeles, The J. Paul Getty Trust, 1997.

Brook, Anthéa, "Dynastic statuary for Charles II of Spain", Antologia di Belle Arti. Nuova serie, La Scultu$r a$, vol. II, 52-55, 1996, pp. 112-125.

Caccioti, Beatrice, "La collezione del VII Marchese del Carpio tra Roma e Madrid", Bolletino d'Arte, 86-87, 1994, pp. 133-196.

Cantone, Gaetana, "Le macchine della festa barocca", en Napoli Barocca, Roma-Bari, Laterza, 1992, pp. 237-239, 244.

Cantone, Gaetana, "Le fontane di Cosimo Fanzago", en Starace, Francesco, L'Acqua e l'Architettura. Acquedotti e fontane del regno di Napoli, Lecce, Edizioni del Grifo, 2002, pp. 342-345, 348.

Carandente, Giovanni, Giacomo Serpotta, Torino, Edizioni RAI Radiotelevisione Italiana, 1967.

Carrió-Invernizzi, Diana, "La estatua de Felipe IV en Santa Maria Maggiore y la embajada romana de Pedro Antonio de Aragón (1664-1666)", Roma moderna e contemporanea revista interdicisplinare di storia, anno XV, 1-3, 2007, Diplomacia e politica della Spagna a Roma. Figure di ambasciatori (M. ${ }^{a}$ A. Visceglia, dir.), pp. 255-270.

Carrió-Invernizzi, Diana, El gobierno de las imágenes. Ceremonial y mecenazgo en la Italia española de la segunda mitad del siglo XVII, Madrid-Frankfurt, Iberoamericana Vervuert, 2008.

\footnotetext{
59 Recientemente se ha publicado una edición facsímil.

${ }^{60}$ Checa Cremades (Comisario), 2003-2004: n. ${ }^{\circ} 5.13$.

${ }^{61}$ El grabado se encuentra en el tomo III (1694), libro quinto, entre las páginas 508 y 509. Un ejemplar suelto de la estampa se conserva en el British Museum (Inv. 1866,1208.948; $215 \times 170 \mathrm{~mm}$ ), que es el que reproducimos.

${ }^{62}$ Para todos los detalles de la azarosa historia del grupo escultórico véase PASCUAL ChENEL, 2012 (en prensa).
} 
Cerezo, Marisol, "Luca Giordano y el virrey Santisteban: un mecenazgo particular", Boletín del Museo e Instituto Camón Aznar, 26, 1986, pp. 73-88.

Checa Cremades, Fernando (comisario), Cortes del Barroco. De Bernini y Velázquez a Luca Giordano, cat. exp. Madrid-Roma, SEACEX-Patrimonio Nacional, 2003-2004.

Colomer, José Luis (dir.), Arte y diplomacia de la Monarquía Hispánica en el siglo XVII, Madrid, Centro de Estudios de Europa Hispánica, 2003.

Colomer, José Luis (dir.), España y Nápoles. Coleccionismo y mecenazgo virreinales en el siglo XVII, Madrid, Centro de Estudios Europa Hispánica, 2009.

Contreras, Jaime, Carlos II el hechizado. Poder y melancolía en la corte del último Austria, Madrid, Temas de Hoy, 2003.

Coppel, Rosario y Herrero Sanz, María Jesús (comisarias), Brillos en bronce. Colecciones de reyes, cat. exp. Madrid, Palacio Real, 2009, pp. 33-34.

Cropper, Elizabeth (ed.), The Diplomacy of Art. Creation and Politics in Seicento Italy, Papers From a Colloquium Held at the Villa Spelmam (7), Florencia, 1998, Milán, 2000.

Dandelet, Thomas James y Marino, John A. (ed.), Spain in Italy. Politics, Society and Religion, 1500-1700, Leiden-Boston, Brill, 2007.

De Cavi, Savina, Architecture and Royal Presence. Domenico and Giulio Cesare Fontana in Spanish Naples (1592-1627), Newcastle, Cambridge Scholars Publishing, 2009.

De Frutos Sastre, Leticia, El VII marqués del Carpio (1629-1687): mecenas y coleccionista de las artes, Tesis Doctoral, Universidad Complutense de Madrid, 2006.

De Frutos Sastre, Leticia, El Templo de la Fama. Alegoría del Marqués del Carpio, Madrid, Fundación de Apoyo a la Historia del Arte Hispánico, 2009a.

De Frutos Sastre, Leticia, "Luca Giordano en la colección napolitana del VII marqués del Carpio", en Colomer, José Luis (dir.), España y Nápoles. Coleccionismo y mecenazgo virreinales en el siglo XVII, Madrid, Centro de Estudios Europa Hispánica, 2009b, pp. 363-378.

Del Pesco, Daniela, "Il viceré del Carpio e la statua equestre di Luigi XIV di Bernini”, en M. G. Bernardini, Maria Grazia (ed.), Studi sul barocco romano. Scritti in onore di Maurizio Fagiolo Dell'Arco, Milano, Skira, 2004, pp. 313-324.

Duque de Maura, Carlos II y su Corte, Madrid, 1911-1915, 2 vols.

Duque de Maura, Vida y reinado de Carlos II, Madrid, Aguilar, 1990 (publicada primero en 1942 en dos volúmenes).

Estella, Margarita, "Adiciones y rectificaciones a noticias sobre esculturas italianas en España", Archivo Español de Arte, 321, 2008, pp. 24-27.

Fagiolo dell'Arco, Maurizio, Berniniana. Novità sul regista del Barocco, Milán, Skira, 2002.

Fernández-Santos Ortiz-Iribas, Jorge, "Un lote de pinturas de la colección del Marqués del Carpio adjudicadas al Duque de Tursi", Reales Sitios, 155, 2003, pp. 42-57.

Fernández Talaya, María Teresa, El Real Sitio de la Florida y la Moncloa. Evolución Histórica y artística de un lugar madrileño, Madrid, Fundación Caja Madrid, 1999.

García Cueto, David, "Presentes de Nápoles. Los virreyes y el envío de obras de arte y objetos suntuarios para la Corona durante el siglo XVII", en Colomer, José Luis (dir.), España y Nápoles. Coleccionismo y mecenazgo virreinales en el siglo XVII, Madrid, Centro de Estudios Europa Hispánica, 2009, pp. 293322.

González Asenjo, Elvira, Don Juan José de Austria y las artes (1629-1679), Madrid, Fundación de Apoyo a la Historia del Arte Hispánico, 2005.

Hellwig Konnerth, Karin, "La estatua ecuestre de Felipe IV de Pietro Tacca y la fachada del Alcázar de Madrid", Archivo Español de Arte, 250, 1990, pp. 233-241.

Hernando Sánchez, Carlos José (coord.), Roma y España. Un crisol de la cultura europea en la Edad Moderna, Actas del Congreso Internacional, Real Academia de España en Roma, 8-12 mayo 2007, Madrid, SEACEX, 2007, 2 vols.

Juderías, Julián, España en tiempo de Carlos II, el Hechizado, Madrid, 1912.

Kamen, Henry, La España de Carlos II, Barcelona, 1981 (publicada primero en inglés obviando el nombre de Carlos II, Spain in the later seventeenth century, 1665-1700).

Lankheit, Klaus, Florentinische Barockplastik.Die Kunst am Hofe der letzten Medici, 670-1743, München, Bruchmann, 1962.

Arch. esp. arte, LXXXV, 338, ABRIL-JUNIO 2012, 165-180, ISSN: 0004-0428 
Lleó Cañal, Vicente, “El virrey IX Conde de Santisteban (1688-1696)”, en Colomer, José Luis (dir.), España y Nápoles. Coleccionismo y mecenazgo virreinales en el siglo XVII, Madrid, Centro de Estudios Europa Hispánica, 2009, pp. 445-460.

Martín García, Juan Manuel, Arte y diplomacia en el reinado de los Reyes Católicos, Madrid, Fundación Universitaria Española, 2002.

Martínez Millán, José y Rivero Rodríguez, Manuel (coords.), Centros de poder italianos en la Monarquía Hispánica (siglos XV-XVIII), Madrid, Polifemo, 2010, 3 vols.

Matilla Rodríguez, José Manuel, El Caballo de Bronce. La estatua ecuestre de Felipe IV. Arte y técnica al servicio de la Monarquía, Madrid, Real Academia de Bellas Artes de San Fernando, 1997.

Matilla Rodríguez, José Manuel, "El caballo de bronce. Problemas técnicos y artísticos de la estatua ecuestre de Felipe IV", Reales Sitios, 141, 1999, pp. 50-59.

Montanari, Tomaso, "Da Luigi XIV a Carlo II. Metamorfosi dell'ultimo capolavoro di Gian Lorenzo Bernini”, en Colomer, José Luis (dir.), Arte y diplomacia de la Monarquía Hispánica en el siglo XVII, Madrid, Centro de Estudios de Europa Hispánica, 2003, pp. 403-413.

Muñoz González, María Jesús, "El IX Conde de Santisteban en Nápoles (1688-1696)", en Colomer, José Luis (dir.), España y Nápoles. Coleccionismo y mecenazgo virreinales en el siglo XVII, Madrid, Centro de Estudios Europa Hispánica, 2009, pp. 461-480.

Nappi, Eduardo, "Documenti su fontane napoletane del seicento", Napoli Nobilissima, vol. XIX, fascicolo V-VI, settembre-dicembre 1980, pp. 220-221, 229-231.

Ostrow, Steven F., "Gian Lorenzo Bernini, Girolamo Lucenti and the Statue of Philip IV in S. Maria Maggiore: Patronage and Politics in Seicento Rome", The Art Bulletin, vol. LXXIII, 1, march 1991, pp. 89-118.

Pascual Chenel, Álvaro, "El retrato de Estado en época Moderna. Teoría, usos y funciones", Torre de los Lujanes, 65, 2009a, pp. 183-223.

Pascual Chenel, Álvaro, “Algunas precisiones en torno al retrato ecuestre de Carlos II de Giovanni Battista Foggini. Relaciones e Influencias", Boletín del Museo del Prado, 45, 2009b, pp. 72-84.

Pascual Chenel, Álvaro, "El monumento ecuestre a Carlos II en la Ciudad de Mesina y el boceto preparatorio de Giacomo Serpotta”, Storia dell'arte, 2012 (en prensa).

Pfandl, Ludwig, Carlos II, Madrid, 1947.

Pita Andrade, José Manuel, "Los cuadros de Velázquez y Mazo que poseyó el séptimo Marqués del Carpio", Archivo Español de Arte, 99, 1952, pp. 223-236.

Ribot, Luis, "La España de Carlos II", en La transición del siglo XVII al XVIII. Entre la decadencia y la reconstrucción, tomo XXVIII de la Historia de España Menéndez Pidal, Madrid, 1993, pp. 63-203.

Ribot, Luis, La Monarquía de España y la guerra de Mesina (1674-1678), Madrid, Actas, 2002.

Ribot, Luis (dir.), Carlos II. El rey y su entorno cortesano, Madrid, Centro de Estudios de Europa Hispánica, 2009.

Rodríguez Ruiz, Delfín, "Sobre el modelo de bronce de la Fontana dei Quattro Fiumi de Gian Lorenzo Bernini conservada en el Palacio Real de Madrid", Reales Sitios, 155, 2003, pp. 26-41.

Salinas, Antonio, "Di un bozzetto del monumento messinese di Carlo II modellato da Giacomo Serpotta", Archivio Storico Siciliano, anno VIII, 1884, pp. 483-490.

Sorrentino, Antonio, “Un bozzetto di Giacomo Serpotta nel museo di Trapani”, Bolletino D'arte, anno VII, fasc. X, 1913, pp. 379-387.

Strazzullo, Franco, Architetti e Ingegnieri Napoletani dal '500 al '700, Nápoles, Benincasa, 1969.

Visceglia, Maria Antonietta, Guerra, Diplomacia y Etiqueta en la corte de los Papas (siglos XVI-XVII), Madrid, Polifemo, 2010.

Wittkower, Rudolf, "The Vicisitudes of a Dynastic Monument. Bernini's Equestrian Statue of Louis XIV”, en De Artibus Opuscula XL. Essays in honour of Erwin Panofsky, Nueva York, 1961, pp. 497-531.

Wittkower, Rudolf, Gian Lorenzo Bernini. El escultor del barroco romano, Madrid, Alianza, 1990 (original en inglés, Gian Lorenzo Bernini. The Sculptor of the Roman Baroque, London, 1955, segunda ed., 1966, tercera, 1981).

Fecha de recepción: 6-VI-2011

Fecha de aceptación: 12-I-2012 